DOI : $10.14746 /$ ps.2019.1.13

\title{
SECURITY PRIORITIES AND THEIR PERCEPTION BY LOCAL COMMUNITIES. A SURVEY OF POPULATION IN WIELKOPOLSKA 2015-2017
}

The survey was carried out in the following context: survey assumptions were developed in mid-2015, which marked a highly important moment in terms of the political debate being held in Poland in relation to both presidential and parliamentary elections. The debate was influenced by arguments of an internal and international nature, addressing both collective and individual security. Electoral and parliamentary debates carried out in political and media spaces were intended to convince potential voters of the presence of a range of threats of varied nature and scope.

Taking into account these circumstances, the survey was carried out in late 2015, and continued in 2016 and 2017. The 2015 survey can be approached as a pilot study which was subsequently continued in the following years, although the survey group is considerably larger than is typical for such studies.

The study attempted to analyze the perceptions of security priorities emerging in public debate among local communities in the Wielkopolska region. The main objective was to verify these priorities in view of actual threats and assess the influence the debate had on the sense of security among the public. This paper is a partial (preliminary) analysis of survey results, since their scope and the material collected cannot feasibly be presented within the framework of the Strategic Review. This paper is a preview of a book which will follow.

\section{METHODOLOGY}

The fundamental methodological premise regarding the scope of the survey was to narrow it down to the territory of Wielkopolska. Given that this region comprises a variety of parts, including its administrative center, Poznan, and formerly independent centers such as Piła, Kalisz, Konin and Leszno, a single territory was selected for the survey. It was conducted in the former region of Konin (województwo konińskie), which constituted a state administrative unit in 1975-1998, and comprised 18 towns and $48 \mathrm{mu}-$ nicipalities before the administrative reform of 1998. It included the counties of Konin, Turek, Słupca and Koło, which are part of the present Wielkopolska region.

This territory was deemed more representative for the whole country than the city of Poznań and the local communities surrounding it. Both in the past and at present, 
Poznań and its neighboring counties have been considered to be more developed and have lower levels of unemployment and higher per capita income compared to the rest of the country. The former region of Konin has suffered the negative impact of the socio-economic transformation after 1989 to a greater extent, which makes it a more relevant point of reference for other regions in Poland.

It has repeatedly been argued in public debate that it is rural and small-town communities that are most interested in receiving support from the central government, thereby forming what is called the 'social electorate.' They are frequently claimed to be supporters of the Law and Justice (PiS) party. This resulted in the survey being narrowed down to this part of the region.

The survey employed the method of direct interviews and served the purpose of verifying hypotheses related to how local communities understand security and to the influence of political debate, the media and international situation on how threats and security priorities are assessed.

The number of questions in the questionnaire was different in every survey cycle but in every case the questionnaire comprised the following fundamental three elements:

1. socio-demographic questions (respondent profile);

2. content-related questions on security;

3. content-related closed and open-ended detailed questions.

The 2015 survey covered a group of 500 people, in 2016 - 540 people, and in 2017 - 646 people. A comparable nationwide survey, conducted by the Centre for Public Opinion Research (CBOS) on the social dimension of security in relation to the "Family 500+" program covered 1,200 respondents (CBOS, 2017).

\section{5 - PRIORITIES IN THE ELECTION YEAR}

In political terms, 2015 marked a watershed for Poland. The election debate resulted in a profound change on the political stage in Poland, particularly the victory of Law and Justice which formed a coalition enabling it to take full authority in Poland.

The author's reflection on the results of the surveys presented herein leads him to believe that this was the outcome of the electoral campaign emphasizing the individual and collective security of the public, among other issues. Another influential factor involved addressing the domestic as well as the international situation.

The survey was conducted at the end of 2015, after Andrzej Duda won the presidential elections and Law and Justice won the elections to the lower and upper chambers of parliament (Sejm and Senate, respectively), therefore questions related to security priorities that had been addressed in the electoral debate were asked.

The main research problem concerned the perception of actual and potential threats to security and its individual aspect. Investigating this issue required the following three basic questions to be asked:

1. Is security understood exclusively in individual terms and is this the prevailing attitude?

2. Does society approach the issue of immigrants, addressed by politicians and the media, as a realistic threat to security? 
3. Does society treat the postulates and promises related to social benefits as realistic?

The main goal of the study was to examine the influence of the political debate in 2015 on the actual perception of individual and collective security. Social needs had a realistic dimension, whereas threats related to such issues as the rising numbers of immigrants or military threats were only a matter of rhetoric.

As was already indicated, the survey included 500 people - 250 men and 250 women. Socio-demographic questions made it possible to determine the main characteristics of the respondent group.

\section{A. Sex of participants}

Table 1

Sex of survey respondents

\begin{tabular}{|l|c|c|}
\hline \multicolumn{1}{|c|}{ Sex } & No. of people & Percentage \\
\hline Women & 250 & 50.0 \\
\hline Men & 250 & 50.0 \\
\hline (N) & 500 & 100.0 \\
\hline
\end{tabular}

Source: Author's elaboration.

Potentially, the emotional engagement in relation to family benefits could be attributed to women to a greater extent than to men. The equal number of respondents of either sex might yield interesting conclusions related to the intensity of the political debate.

\section{B. Age of survey participants}

Age of survey participants

\begin{tabular}{||l|c|c||}
\hline \multicolumn{1}{|c|}{ Age } & No. of people & Percentage \\
\hline Up to 20 years & 55 & 11.0 \\
\hline 20-30 years & 175 & 35.0 \\
\hline 31-45 years & 150 & 30.0 \\
\hline 46-65 years & 95 & 19.0 \\
\hline Over 65 years & 25 & 5.0 \\
\hline (N) & 500 & 100.0 \\
\hline
\end{tabular}

Source: Author's elaboration.

It can be seen in the table above that the majority of survey participants fell in the 20-45 age bracket. This group can be considered to be potentially the most interested in obtaining family benefits which directly translate into individual economic security. This was one of the main political promises made in the 2015 elections. This age group also uses both online information platforms and traditional media. 


\section{Respondents' place of residence}

Table 3

Respondents' place of residence

\begin{tabular}{||l|c|c||}
\hline \multicolumn{1}{|c|}{ Place of residence } & No. of people & Percentage \\
\hline Rural areas & 175 & 35.0 \\
\hline Towns with population $<2,000$ & 80 & 16.0 \\
\hline Towns with population $2,000-50,000$ & 160 & 32.0 \\
\hline Towns with population $>50,000$ & 85 & 17.0 \\
\hline (N) & 500 & 100.0 \\
\hline
\end{tabular}

Source: Author's elaboration.

Taking into account the fact that Konin is the only town with population of over 50,000 in the territory surveyed, and that the remaining towns of Turek, Koło and Słupca have populations below 30,000, the above data can be deemed representative for rural and small-town communities.

\section{Respondents' level of education}

Table 4

Respondents' level of education

\begin{tabular}{||l|c|c|}
\hline \hline \multicolumn{1}{|c|}{ Education } & No. of people & Percentage \\
\hline Elementary & 25 & 5.0 \\
\hline Vocational & 130 & 26.0 \\
\hline Secondary & 265 & 53.0 \\
\hline Higher & 80 & 16.0 \\
\hline$(\mathrm{N})$ & 500 & 100.0 \\
\hline
\end{tabular}

Source: Author's elaboration.

The largest proportion of survey participants had secondary education and the smallest - elementary education. This corresponds to age groups, where the smallest group was respondents over 65, who are likely to account for the largest proportion of people that have not benefited from educational progress after 1989.

As regards content-related questions on security, those directly related to the assessment of individual and collective security will be given most attention. The following question served the purpose: What does the term 'security' mean to you? (a) absence of personal threats; (b) absence of threats to families; (c) absence of threats to local communities; (d) absence of threats to the state/citizens. It was assumed that the most popular answer in all age groups would involve individual and family security, but that an intense political debate on external threats may translate into a relatively high level of priority assigned to collective security.

Answering the above question, 430 people indicated a single option, yielding the following results. 
Perception of security (priorities)

\begin{tabular}{|l|c|c||}
\hline \multicolumn{1}{|c|}{ Perception of security } & No. of people & Percentage \\
\hline absence of personal threats & 105 & 24.42 \\
\hline absence of threats to families & 130 & 30.23 \\
\hline absence of threats to local communities & 35 & 8.14 \\
\hline absence of threat to the state/citizens & 160 & 37.21 \\
\hline (N) & 430 & 100.0 \\
\hline
\end{tabular}

Source: Author's elaboration.

Although it is true that over half of respondents (54.65\%) indicated either personal or family security as priorities in their perception of security, the general understanding of security as that of state/society prevailed (37.21\%). This confirms the assumption that, in spite of significant individual or even personal interests, the atmosphere of external threat has an essential influence on priorities. To what extent these priorities are related to political discourse and media coverage will be demonstrated after detailed content-related questions are analyzed.

Detailed issues were examined in relation to immigrants, military security and financial resources making it possible to launch social programs. Regarding immigrants, the majority of respondents were assumed to have been strongly influenced by the media and political campaign, resulting in potentially negative attitudes towards immigrants regardless of the reality of the situation. In terms of Poland's defense potential, it was assumed that the scale of threats presented in public debate and the media, and related primarily to potential aggression from Russia, might have influenced the assessment of the military forces and measures available to Poland. Finally, contradictory information on threats following from social benefits offered by the state might have a significant impact on social proposals being assessed as unrealistic.

The attitude to the issue of migrants and related threats was examined by the following question, among others: Do you feel safe given emerging problems related to the wave of migration coming to Europe?

A majority of respondents indicated that they felt threatened. The table below demonstrates that this was the case in all age groups, and among residents of both rural and urban areas to a similar extent.

The sense of threat related to the influx of immigrants in general

\begin{tabular}{|c|c|c||}
\hline $\begin{array}{c}\text { Do you feel safe given the influx } \\
\text { of immigrants to Europe? }\end{array}$ & No. of people & Percentage \\
\hline Yes & 160 & 32.0 \\
\hline No & 340 & 68.0 \\
\hline (N) & 500 & 100.0 \\
\hline
\end{tabular}

Source: Author's elaboration. 
Age groups of respondents declaring their sense of threat

\begin{tabular}{||l|c|c||}
\hline \multicolumn{1}{|c|}{ Sense of threat } & No. of people & Percentage \\
\hline People $<20($ Yes) & 45 & 9.0 \\
\hline People $<20($ No) & 10 & 3.0 \\
\hline People aged 20-30 (Yes) & 115 & 23.0 \\
\hline People aged 20-30 (No) & 60 & 12.0 \\
\hline People aged 31-45(Yes) & 100 & 20.0 \\
\hline People aged 31-45 (No) & 50 & 10.0 \\
\hline People aged 46-65 (Yes) & 70 & 14.0 \\
\hline People aged 46-65 (No) & 25 & 5.0 \\
\hline People $>65($ Yes) & 10 & 2.0 \\
\hline People $>65(\mathrm{No})$ & 500 & 3.0 \\
\hline (N) & \multicolumn{2}{|c||}{} \\
\hline
\end{tabular}

Source: Author's elaboration.

The sense of threat due to immigrants is indicated by a lower proportion of respondents in the smallest age group (people over 65) compared to all the remaining groups.

Table 8

People declaring feeling threatened by place of residence

\begin{tabular}{||l|c|c||}
\hline \multicolumn{1}{|c|}{ Sense of threat } & No. of people & Percentage \\
\hline Rural areas (Yes) & 135 & 27.0 \\
\hline Rural areas (No) & 40 & 8.0 \\
\hline Towns with population $<2,000($ Yes) & 55 & 11.0 \\
\hline Towns with population $<2,000(\mathrm{No})$ & 25 & 5.0 \\
\hline Towns with population $2,000-50,000($ Yes) & 100 & 20.0 \\
\hline Towns with population $2,000-50,000(\mathrm{No})$ & 60 & 12.0 \\
\hline Towns with population $<50,000(\mathrm{Yes})$ & 50 & 10.0 \\
\hline Towns with population $>50,000(\mathrm{No})$ & 35 & 7.0 \\
\hline$(\mathrm{N})$ & 500 & 100.0 \\
\hline
\end{tabular}

Source: Author's elaboration.

The influence of the media on the sense of threat in relation to the place of residence is confirmed. The greatest sense of threat is declared by inhabitants of rural areas and the smallest - by residents of Konin, although the latter are much more likely to encounter immigrants.

Regarding the sense of security in relation to military threats, the election debate emphasized priorities of the state in this respect. It was examined, inter alia, by asking the following question: In your opinion, does Poland have sufficient resources to defend the country, strengthen the army and protect the eastern border? It was assumed that news stories relating to threats and the assessment of the situation from this perspective would translate into a pessimistic assessment of Poland's potential in this area. On the other hand, media coverage influenced the demands to improve the situation.

The results presented below demonstrate that this assumption was fully confirmed. A majority of respondents pointed to the low defense potential of Poland, indirectly confirming the influence of the media and arguments employed in political debates. 
Assessment of sufficient defense resources

\begin{tabular}{|c|c|c|}
\hline $\begin{array}{c}\text { Do you feel that Poland has sufficient } \\
\text { resources to be used for defense? }\end{array}$ & No. of people & Percentage \\
\hline Yes & 115 & 23.0 \\
\hline No & 385 & 77.0 \\
\hline$(\mathrm{N})$ & 500 & 100.0 \\
\hline
\end{tabular}

Source: Author's elaboration.

Similar opinions were shared in all age groups and no differentiation by place of residence was observed.

Table 10

Assessment of sufficient defense resources by age groups

\begin{tabular}{||l|c|c||}
\hline \multicolumn{1}{|c|}{$\begin{array}{c}\text { Assessment of sufficient defense } \\
\text { resources }\end{array}$} & No. of people & Percentage \\
\hline People $<20($ Yes) & 5 & 1.0 \\
\hline People $<20$ (No) & 50 & 10.0 \\
\hline People aged 20-30 (Yes) & 50 & 10.0 \\
\hline People aged 20-30 (No) & 125 & 25.0 \\
\hline People aged 31-45 (Yes) & 40 & 8.0 \\
\hline People aged 31-45 (No) & 110 & 22.0 \\
\hline People aged 46-65 (Yes) & 15 & 3.0 \\
\hline People aged 46-65 (No) & 80 & 16.0 \\
\hline People over 65 (Yes) & 10 & 2.0 \\
\hline People over 65 (No) & 15 & 3.0 \\
\hline$(\mathrm{N})$ & 500 & 100.0 \\
\hline
\end{tabular}

Source: Author's elaboration.

Table 11

Assessment of sufficiency of defense resources by place of residence

\begin{tabular}{||l|c|c||}
\hline \multicolumn{1}{|c|}{$\begin{array}{c}\text { Assessment of sufficiency of defense } \\
\text { resources }\end{array}$} & No. of people & Percentage \\
\hline Rural areas (Yes) & 35 & 7.0 \\
\hline Rural areas (No) & 140 & 28.0 \\
\hline Towns with population $<2,000($ Yes) & 15 & 3.0 \\
\hline Towns with population $<2,000(\mathrm{No})$ & 65 & 13.0 \\
\hline Towns with population $>2,000($ Yes) & 50 & 10.0 \\
\hline Towns with population $>2,000(\mathrm{No})$ & 110 & 22.0 \\
\hline Towns with population $<50,000(\mathrm{Yes})$ & 20 & 4.0 \\
\hline Towns with population $>50,000(\mathrm{No})$ & 65 & 13.0 \\
\hline (N) & 500 & 100.0 \\
\hline
\end{tabular}

Source: Author's elaboration.

The final issue regarded the realistic nature and feasibility of the implementation of election promises related to social matters. The question addressing this read as follows: Are you concerned about the financial condition of Poland after the social reforms $(500+$, medicines and lower retirement age) are launched? 
It was assumed that, in spite of a negative campaign by the opposition and critics of those changes, social expectations would outweigh concerns and voters from small towns and rural areas would believe that the promises made by Law and Justice could be fulfilled.

The results presented below show that the need for changes and increased social expectations were definitely stronger than concerns. The negative impact exerted in the course of the campaign was not strong enough to mitigate those expectations. The good financial condition of the state which was experienced by a majority of society can also be assumed to have influenced this assessment.

Table 12

Concern about the condition of state finances after launching social reforms

\begin{tabular}{|c|c|c||}
\hline $\begin{array}{c}\text { Concern about the condition of state } \\
\text { finances after launching social reforms }\end{array}$ & No. of people & Percentage \\
\hline Yes & 150 & 30.0 \\
\hline No & 350 & 70.0 \\
\hline (N) & 500 & 100.0 \\
\hline
\end{tabular}

Source: Author's elaboration.

The 2015 survey clearly indicated the influence of the media and election debate on the perception of individual and collective security, taking into account a number of its components. State interests and general threats turned out to have a higher priority than individual security. On the other hand, social expectations related to the announced reforms outweighed fears related to their adverse impact.

Further studies were recommended to continue the observation of the social reception of these reforms, if they are launched, and of security assessment, assuming that a number of arguments would no longer be used in public debate after the elections. In practice, these conclusions resulted in the 2015 survey results not being published in order to use them for comparison with studies in subsequent years.

\section{6 - PRIORITIES IN THE YEAR OF FULFILLING SOCIAL PROMISES}

2016 marked an important period as the first stage of fulfilling social promises made by Law and Justice, its consolidation of power and the perception of domestic and external problems in terms of a long-term strategy rather than immediate actions related to fulfilling electoral promises. Politicians who had made promises in the field of security became the implementers of their obligations. The narrative related to immigrants and the military threat from the East was maintained among the ruling party. Fulfilling the electoral social promises, childcare benefits were introduced (Law of February 11, 2016 on state aid in childcare) and the retirement age was lowered (Law of November 16, 2016 amending the law on pensions and benefits granted by the Social Security Fund and certain other laws).

Regarding security, the electoral promise to establish Territorial Defense Forces was fulfilled (Law of November 16, 2016 amending the law on the universal obligation to defend the Republic of Poland and certain other laws), which announced increased defense potential through the establishment of such forces. 
This was accompanied by increasing internal conflict triggered by changes to internal legislation concerning the judiciary, which transformed into an external conflict. The issue of the Constitutional Tribunal was and continues to be the subject of harsh polemics and criticism expressed both domestically and internationally. This strengthened the narrative of Poland's security, which was clearly perceived by society as contradictory messages.

In such circumstances, it was resolved that the 2015 studies should continue. The main research topic related to the perception of realistic and potential threats to security in individual and collective terms was continued. In order to examine this problem, the following three fundamental questions were identified:

1. Is security understood exclusively in individual terms and is this the prevailing attitude?

2. Does society approach the issue of immigrants, addressed by politicians and the media, as a realistic threat to security?

3. Have the social reforms launched had a tangible impact on how the public perceives security?

The main objective of the study was to assess the influence of Law and Justice fulfilling its electoral promises on the actual perception of individual and collective security at the end of 2016. This time the survey covered 540 people. Socio-demographic questions made it possible to determine the main characteristics of the respondent group.

\section{A. Sex of participants}

Table 13

Sex of survey participants -2016

\begin{tabular}{|l|c|c|}
\hline \multicolumn{1}{|c|}{ Sex } & No. of people & Percentage \\
\hline Women & 292 & 54.0 \\
\hline Men & 248 & 46.0 \\
\hline (N) & 540 & 100.0 \\
\hline
\end{tabular}

Source: Author's elaboration.

The proportion of female respondents increased by $6 \%$. This was significant, as women were the main beneficiaries of the social reforms launched.

\section{B. Age of survey participants}

Table 14

Age of survey participants - 2016

\begin{tabular}{|l|c|c|}
\hline \multicolumn{1}{|c|}{ Age } & No. of people & Percentage \\
\hline Up to 20 years & 112 & 21.0 \\
\hline 20-30 years & 127 & 24.0 \\
\hline 31-45 years & 135 & 25.0 \\
\hline 46-65 years & 115 & 21.0 \\
\hline Over 65 years & 51 & 9.0 \\
\hline (N) & 540 & 100.0 \\
\hline
\end{tabular}

Source: Author's elaboration. 
The majority of survey participants fell in the $20-45$ age bracket. This group can be considered to be potentially the most interested in obtaining family benefits which directly translate into individual economic security. At the same time, the number of people potentially interested in changes to the retirement age increased.

\section{Respondents' place of residence}

Table 15

Respondents' place of residence - 2016

\begin{tabular}{||l|c|c||}
\hline \multicolumn{1}{|c|}{ Place of residence } & No. of people & Percentage \\
\hline Rural areas & 266 & 49.0 \\
\hline Towns with population $<2,000$ & 45 & 8.0 \\
\hline Towns with population $2,000-50,000$ & 86 & 16.0 \\
\hline Towns with population $>50,000$ & 142 & 26.0 \\
\hline (N) & 540 & 100.0 \\
\hline
\end{tabular}

Source: Author's elaboration.

Also in this study, inhabitants of rural areas and small towns were the most numerous; nevertheless the proportion of respondents from the town of Konin increased by $9 \%$ compared to 2015 . This was significant since the social changes that had been launched could be observed and experienced by a majority of society.

\section{Respondents' level of education}

Table 16

Survey respondents' level of education - 2016

\begin{tabular}{|l|c|c|}
\hline \multicolumn{1}{|c|}{ Education } & No. of people & Percentage \\
\hline Elementary & 52 & 10.0 \\
\hline Vocational & 105 & 19.0 \\
\hline Secondary & 257 & 48.0 \\
\hline Higher & 126 & 23.0 \\
\hline (N) & 500 & 100.0 \\
\hline
\end{tabular}

Source: Author's elaboration.

As in 2015, the largest proportion of survey participants in 2016 had secondary education and the smallest - elementary education.

In 2016, the fundamental content-related question on security was also the same, namely: What does the term 'security' mean to you? (a) absence of personal threats; (b) absence of threats to families; (c) absence of threats to local communities; (d) absence of threats to the state/citizens. It was assumed that, since the rhetoric associated with the elections was no longer current and tensions related to external security had decreased, individual and family security should be more of a priority.

Answering the above question, 500 people indicated a single option, yielding the following results. 
Perception of security (priorities) - 2016

\begin{tabular}{|l|c|c||}
\hline \multicolumn{1}{|c|}{ Perception of security } & No. of people & Percentage \\
\hline Absence of personal threats & 111 & 22.0 \\
\hline Absence of threats to families & 133 & 27.0 \\
\hline Absence of threats to local communities & 55 & 11.0 \\
\hline Absence of threats to the state/citizens & 201 & 40.0 \\
\hline$(\mathrm{N})$ & 500 & 100.0 \\
\hline
\end{tabular}

Source: Author's elaboration.

The assumption that priorities would move away from general security of the state/society was not confirmed. On the contrary, the number of people choosing individual security fell by $2.5 \%$, and the number of respondents choosing family security dropped by over $3 \%$. The number of people for whom the security of the state/society was a priority increased by $3 \%$, accounting for the largest proportion of respondents. Also, the number of people for whom the security of local communities was a priority increased by nearly $3 \%$. This confirms the fact that even though the social reforms had direct influence on individual security, the atmosphere of external threat continued to have a crucial influence on the priorities. This is most likely to have been related to the continued political and media narrative of threats posed by external forces. Another frequently employed narrative involved the treason of Poland abroad, particularly the activity of the political opposition in European Union institutions.

Analyzing detailed issues, the question regarding immigrants was repeated: Do you feel safe given emerging problems related to the wave of migration coming to Europe? A majority of respondents indicated their feelings of threat. The table below demonstrates that this was the case in all age groups, and among residents of both rural and urban areas to a similar extent.

The sense of threat related to the arrival of immigrants in general - 2016

\begin{tabular}{|c|c|c|}
\hline $\begin{array}{c}\text { Do you feel safe given the wave } \\
\text { of immigration to Europe? }\end{array}$ & No. of people & Percentage \\
\hline Yes & 135 & 25.0 \\
\hline No & 405 & 75.0 \\
\hline$(\mathrm{N})$ & 540 & 100.0 \\
\hline
\end{tabular}

Source: Author's elaboration.

The sense of threat and decrease in sense of security by $7 \%$ could have been related to intensified rhetoric of the authorities, which justified their relentless standpoint regarding Poland's acceptance of refugees, and to the media, which emphasized the difficulties other EU states were having in this regard. Another significant factor could be related to politicians addressing terrorist threats, and associating this threat unequivocally with the arrival of immigrants from the Middle East and Africa. As can be seen, a sense of threat was declared by people in all age groups. The highest increase could 
be observed in the group of the youngest respondents (under 20) - 7\% - and among the oldest (over 65) $-6 \%$.

Age groups of respondents declaring their sense of threat - 2016

\begin{tabular}{||l|c|c||}
\hline \multicolumn{1}{|c|}{ Sense of threat } & No. of people & Percentage \\
\hline People under 20 (Yes) & 86 & 16.0 \\
\hline People under 20 (No) & 26 & 5.0 \\
\hline People aged 20-30(Yes) & 101 & 19.0 \\
\hline People aged 20-30 (No) & 26 & 5.0 \\
\hline People aged 31-45(Yes) & 94 & 17.0 \\
\hline People aged 31-45 (No) & 41 & 8.0 \\
\hline People aged 46-65 (Yes) & 83 & 15.0 \\
\hline People aged 46-65 (No) & 32 & 6.0 \\
\hline People over 65 (Yes) & 41 & 8.0 \\
\hline People over 65 (No) & 10 & 2.0 \\
\hline (N) & 540 & 100.0 \\
\hline
\end{tabular}

Source: Author's elaboration.

The terrorist threat was one of the main arguments wielded by Law and Justice in the debate on whether or not to accept refugees. The 2016 survey featured an additional direct and detailed question on this topic: In your opinion, is Poland's security strongly associated with terrorist threats?

This question once again could verify the conviction that the media exert profound influence on how this issue is perceived. So far, Poland has not been of interest to terrorists and all experiences and opinions could only have been related to politicians' statements and media coverage.

Opinions on Poland's security in the context of terrorist threat - 2016

\begin{tabular}{|c|c|c||}
\hline $\begin{array}{c}\text { In your opinion, is Poland's security } \\
\text { strongly associated with terrorist threats? }\end{array}$ & No. of people & Percentage \\
\hline Yes & 163 & 30.2 \\
\hline No & 377 & 69.8 \\
\hline (N) & 540 & 100.0 \\
\hline
\end{tabular}

Source: Author's elaboration.

As demonstrated above, although the media report terrorist events, this issue does not have as strong an influence as the issue of refugees does. It can be inferred that respondents assess terrorist threats from the point of view of their likeliness.

Another detailed question added in 2016 concerned the threat related to Russia. This threat was addressed in public debate and the media in relation to Ukraine and the necessity of having NATO troops stationed in Poland. It was assumed that a majority of respondents would perceive the threat related to Russia. In order to verify this assumption, the following question was asked: In your opinion, are we in danger due to Russia's policy? The results are presented below. 
The sense of threat due to Russia's policy - 2016

\begin{tabular}{|c|c|c|}
\hline $\begin{array}{c}\text { In your opinion, are we in danger } \\
\text { due to Russia's policy? }\end{array}$ & No. of people & Percentage \\
\hline Yes & 330 & 61.0 \\
\hline No & 210 & 39.0 \\
\hline (N) & 540 & 100.0 \\
\hline
\end{tabular}

Source: Author's elaboration.

Over $60 \%$ of respondents indicated feeling threatened by Russia. Nevertheless, this level is lower than could be expected in light of political statements and news on Russia presented in the Polish media.

The final detailed question concerned social matters: Do you feel safer as a result of the social activities of the government? It was assumed that the majority should declare an increased sense of security as electoral promises had been fulfilled.

Table 22

Sense of security related to the implementation of social reforms - 2016

\begin{tabular}{|c|c|c|}
\hline $\begin{array}{c}\text { Do you feel safer as a result of social } \\
\text { activities of the government? }\end{array}$ & No. of people & Percentage \\
\hline Yes & 237 & 44.0 \\
\hline No & 303 & 56.0 \\
\hline$(\mathrm{N})$ & 540 & 100.0 \\
\hline
\end{tabular}

Source: Author's elaboration.

The assumptions were not confirmed and the personal sense of security did not rise following the launch of social programs. Combined with the fact that priority was given to the security of the state/society, it can be inferred that the success of Law and Justice was the outcome of more than just individual security priorities. The claim that a social benefits-driven electorate comprised of the beneficiaries of social reforms prevailed was not confirmed.

\section{7 - PRIORITIES IN THE YEAR OF ASSESSING THE FEASIBILITY OF ELECTORAL PROMISES BEING FULFILLED}

For Law and Justice and other parties forming the parliamentary majority, 2017 was the period when the importance of Poland in the international arena, as well as Poland's security, were declared to have improved. This followed from the 2016 NATO Summit and the decision to strengthen NATO's eastern flank and to deploy four battle groups in Baltic states and in Poland, alongside the heavy-armored brigade divisions of the U.S. Army. In July 2017, U.S. President Donald Trump visited Poland and confirmed U.S. obligations towards the Alliance. Poland was also chosen as a non-permanent member of the UN Security Council.

Internally, security priorities could have been influenced by the experience of the "Family 500+" program, which had been launched over a year before, and the entry 
into force of regulations lowering the retirement age. The government also started a campaign promoting an accommodation-focused "Apartment plus" program.

Under these circumstances, it was decided that the studies from 2015 and 2016 should be continued. The research problem, related to the perception of realistic and potential threats to security and its individual and collective relevance, remained current. It was also stated that the following three fundamental questions need to be answered to address the research problem:

1. Is security still perceived in collective rather than individual terms, as indicated in the former studies?

2. Does society treat the immigration issue, which continues to be raised by politicians and the media, as a realistic threat to security?

3. Have the social reforms launched translated into a sense of security among the public?

The main objective of the study was to assess the influence that the policy of Law and Justice had on the perception of individual and collective security among the public at the end of 2017, both in terms of domestic and international matters.

This time, the survey covered 646 people. Socio-demographic questions made it possible to determine the main characteristics of the respondent group.

\section{A. Sex of participants}

Table 23

Sex of survey participants -2017

\begin{tabular}{|l|c|c|}
\hline \multicolumn{1}{|c|}{ Sex } & No. of people & Percentage \\
\hline Women & 356 & 55.0 \\
\hline Men & 290 & 45.0 \\
\hline$(\mathrm{N})$ & 646 & 100.0 \\
\hline
\end{tabular}

Source: Author's elaboration.

This time, the women accounted for only $5 \%$ more of respondents than men. Their number exceeded that of female participants in the 2016 survey by $1 \%$.

\section{B. Age of survey participants}

Table 24

Age of survey participants - 2017

\begin{tabular}{|l|c|c|}
\hline \multicolumn{1}{|c|}{ Age } & No. of people & Percentage \\
\hline Up to 20 years & 116 & $21.0(18.0)$ \\
\hline 20-30 years & 181 & $24.0(28.0)$ \\
\hline $31-45$ years & 176 & $25.0(27.0)$ \\
\hline 46-65 years & 127 & $21.0(20.0)$ \\
\hline Over 65 years & 46 & $9.0(7.0)$ \\
\hline$(\mathrm{N})$ & 646 & 100.0 \\
\hline
\end{tabular}

Source: Author's elaboration. 
The majority of survey participants fell in the 20-45 age bracket and their number rose by $6 \%$ compared to 2016 . The proportion of people under twenty years of age dropped by $3 \%$. Age proportions set in former studies were maintained.

\section{Respondents' place of residence}

Table 25

Respondents' place of residence -2017

\begin{tabular}{||l|c|c||}
\hline \multicolumn{1}{|c|}{ Place of residence } & No. of people & Percentage \\
\hline Rural areas & 285 & $49.0(44)$ \\
\hline Towns with population $<2000$ & 43 & $8.0(7)$ \\
\hline Towns with population $2000-50000$ & 151 & $16.0(23)$ \\
\hline Towns with population $>50000$ & 180 & $26.0(28)$ \\
\hline (N) & 646 & 100.0 \\
\hline
\end{tabular}

Source: Author's elaboration.

Again, inhabitants of rural areas and small towns predominated, although the number of the former dropped by $5 \%$ while the proportion of inhabitants of Konin increased by $2 \%$.

\section{Respondents' level of education}

Table 26

Survey respondents' level of education - 2017

\begin{tabular}{|l|c|c|}
\hline \multicolumn{1}{|c|}{ Education } & No. of people & Percentage \\
\hline Elementary & 46 & 7.0 \\
\hline Vocational & 115 & 18.0 \\
\hline Secondary & 283 & 44.0 \\
\hline Higher & 177 & 27.0 \\
\hline (N) & 646 & 100.0 \\
\hline
\end{tabular}

Source: Author's elaboration.

This time, as was the case in 2015 and 2016, the largest proportion of survey participants had secondary education and the smallest - elementary education.

The question regarding security was repeated. It was assumed that the increased number of messages about Poland's increased external security would translate into respondents' increased interest in priorities related to individual and family security.

500 people indicated a single option, yielding the following results.

Table 27

Perception of security (priorities) - 2017

\begin{tabular}{|l|c|c|}
\hline \multicolumn{1}{|c|}{ Perception of security } & No. of people & Percentage \\
\hline Absence of personal threats & 115 & 22.0 \\
\hline Absence of threats to families & 212 & 40.0 \\
\hline Absence of threats to local communities & 29 & 5.0 \\
\hline Absence of threat to the state/citizens & 172 & 33.0 \\
\hline$(\mathrm{N})$ & 528 & 100.0 \\
\hline
\end{tabular}

Source: Author's elaboration. 
The assumption that priorities should move from general security of the state/society to individual and family security was confirmed as regards the latter. For the first time in three years, family security became the main priority, increasing by $13 \%$ compared to 2016. Individual security, however, remained at the same level. Security of the state lost its priority status and dropped by $7 \%$, while security of local communities dropped by $6 \%$. This confirms that family security was prioritized due to social reforms, mainly the "Family 500+," which turned out to be realistic, as well as messages about Poland's security received by the public. This was most likely related to a continued political and media narrative where these topics were prioritized. The information policy of Law and Justice and the government, aiming to maintain high social support by stressing social reforms and Poland's security, proved effective.

When analyzing detailed problems, an open-ended question was asked: In your opinion, what poses a threat to Poland's security? This question was answered by 535 out of 646 people. 136 of them indicated the issue of immigration, 77 mentioned terrorism, 34 pointed out threats related to Islam, and only 4 referred to threats related to Russia and 6 to a threat of war. The remaining 278 people indicated internal problems, such as alcoholism (15), drug use (32), a variety of aspects related to behavior on the political stage (62), and many others. This shows that society is highly aware of threats related to immigration, terrorism and Islam, which are typically strongly interrelated in the public consciousness. It can be argued that the information policy of the government had a substantial impact here, along with the anti-immigration sentiments it generated. Matters related to the threat from Russia or an armed conflict completely disappeared. In order to further examine these aspects, continued and more detailed investigation is recommended. This will make it possible to determine the extent and scale to which security-related activities had an impact on the decreased perception of this threat and to what extent this might be the outcome of the media no longer emphasizing the anti-Russia narrative.

As significant social reforms associated with the implementation of the "Family 500+" program were consolidated, the 2017 study was to take a more detailed approach to social security. A direct question on the assessment of the state's family policy was asked in order to review the opinions and narrative of the government praising the positive outcomes of the "Family 500+" program.

Table 28

Assessment of the state's family policy - 2017

\begin{tabular}{|c|c|c|}
\hline $\begin{array}{l}\text { What is your assessment of the state's } \\
\text { family policy? }\end{array}$ & No. of people & Percentage \\
\hline Very good & 74 & 11.0 \\
\hline Good & 190 & 29.0 \\
\hline Satisfactory & 143 & 22.0 \\
\hline Unsatisfactory & 77 & 12.0 \\
\hline Hard to say & 162 & 25.0 \\
\hline (N) & 646 & 100.0 \\
\hline
\end{tabular}

Source: Author's elaboration.

The analysis of answers in the table above shows that the majority hold positive opinions, and a total of $40 \%$ of respondents assess the state policy in this field as very 
good and good. Many respondents (25\%) had no opinion, which means that either they are not interested in the matter or that the media information campaign was ineffective in this respect. Many respondents assess this policy as unsatisfactory (12\%) or merely satisfactory (22\%) which accounts for a total of $34 \%$. This may be interpreted as meaning that the activities of the government are not entirely approved of, or that they are not comprehensive. The results pertaining to the "Family 500+" program show the prevalence of positive assessments.

Table 29

Assessment of the government's activity in relations to the implementation of the "Family $500+$ " program

\begin{tabular}{||l|c|c||}
\hline \multicolumn{1}{|c|}{$\begin{array}{c}\text { Is this a good activity on the part } \\
\text { of the government? }\end{array}$} & No. of people & Percentage \\
\hline Yes & 299 & 46.0 \\
\hline Rather yes & 170 & 26.0 \\
\hline No & 101 & 16.0 \\
\hline No opinion & 76 & 12.0 \\
\hline (N) & 646 & 100.0 \\
\hline
\end{tabular}

Source: Author's elaboration.

An extremely high percentage of respondents indicated their personal support for the "Family 500+" program, although only 215 of them (33\%) had children.

Table 30

Personal support for the "Family 500+" program

\begin{tabular}{|c|c|c|}
\hline $\begin{array}{c}\text { Do you support the "Family 500+" } \\
\text { program? }\end{array}$ & No. of people & Percentage \\
\hline Yes & 428 & 66.0 \\
\hline No & 218 & 34.0 \\
\hline$(\mathrm{N})$ & 646 & 100.0 \\
\hline
\end{tabular}

Source: Author's elaboration.

A majority of survey respondents were of the opinion that the program improved the situation of poor families in Poland.

Table 31

Opinions on the influence of the "Family 500+" program on the situation of poor families in Poland

\begin{tabular}{||l|c|c||}
\hline $\begin{array}{c}\text { Has the "Family 500+" program im- } \\
\text { proved the situation of poor families in } \\
\text { Poland? }\end{array}$ & No. of people & Percentage \\
\hline Yes & 509 & 79.0 \\
\hline No & 66 & 10.0 \\
\hline No opinion & 71 & 11.0 \\
\hline (N) & 646 & 100.0 \\
\hline
\end{tabular}

Source: Author's elaboration. 
The study also attempted to review the assessments of the financial form of the benefit, because both the political debate and the media frequently addressed the issue of abuse due to the fact that children are not the actual beneficiaries. It was found out that the largest proportion of respondents (52\%) claimed that the program is abused, whereas only $23 \%$ denied this. This means that, irrespective of benefiting from the program, members of the public carefully scrutinize the behavior of the beneficiaries of this benefit. This was confirmed in studies on the form of the benefit. Only $43 \%$ of respondents supported the financial form of the benefit. A majority (45\%) would prefer mixed benefits and $12 \%$ opted for a solely non-financial form of the benefit.

Table 32

Opinions on the "Family $500+$ " program being abused

\begin{tabular}{||l|c|c||}
\hline \hline \multicolumn{1}{|c|}{$\begin{array}{c}\text { Is the "Family 500+" program being } \\
\text { abused? }\end{array}$} & No. of people & Percentage \\
\hline Yes & 336 & 52.0 \\
\hline No & 147 & 23.0 \\
\hline No opinion & 163 & 25.0 \\
\hline$(\mathrm{N})$ & 646 & 100.0 \\
\hline
\end{tabular}

Source: author's elaboration.

Table 33 .

Opinions on the form of the benefit offered under the "Family 500+" program

\begin{tabular}{|l|c|c||}
\hline $\begin{array}{c}\text { Respondents' opinions on the form of the benefit offered under } \\
\text { the "Family 500+" program }\end{array}$ & No. of people & Percentage \\
\hline Financial benefit only & 278 & 43.0 \\
\hline Mixed benefits (financial aid combined with other forms of benefits) & 288 & 45.0 \\
\hline Non-financial benefits only & 80 & 12.0 \\
\hline (N) & 646 & 100.00 \\
\hline
\end{tabular}

Source: author's elaboration.

In the conclusion of the 2017 study, it can be said that, compared to earlier studies, the security priorities changed from those of collective security of the state/society to individual priorities related to individual and family security. This was the year in which Law and Justice consolidated its position, launching its social programs including, first and foremost, the "Family 500+" program, and taking steps aimed at increasing the declared level of Poland's security, so these results should not come as a surprise.

The election strategy and political practice addressing the collective and individual dimensions of security proved effective, as shown by its assessment by a local community of inhabitants of the former region of Konin. Interestingly, a majority of respondents attributed a relatively low priority to local communities.

$$
* * *
$$

This paper aims to present the results of studies that were carried out over three years $(2015,2016$ and 2017) to examine the perception of the security priorities of local 
communities. These local communities were represented by inhabitants of a specific part of Wielkopolska, namely of the former administrative region of Konin. The studies were conducted in the specific political and media-related context of the 2015 elections, and the fulfilment of promises made by the elections winners - Law and Justice. The studies concerned both individual and collective security and external threats.

The above-presented results of this study demonstrate that the influence of political discourse is crucial for the perception of security priorities. This could be seen in the priorities relating to collective security (studies in 2015 and 2016) and individual and family security (study in 2017).

Security-related arguments have a tangible dimension in the Polish political arena and society, affecting the security priorities indicated by the public. Emphasizing the presence of external threats intensifies concerns with the security of the state and the whole of society. Nevertheless, some threats clearly are media creations only, as evidenced by the perceived threat of an influx of immigrants and terrorism.

Activities related to international security and the state's actions in this field have a symbolic significance and exert a similar influence.

The launching of social programs and reducing the threat rhetoric employed during the electoral campaigns has increased the sense of individual security among society, as observed in relation to the implementation of the "Family 500+" program.

The studies are recommended to be continued, especially in order to review the assumptions and practice of social reforms.

\title{
REFERENCES
}

CBOS (2017), Ocena programu „Rodzina 500 plus” po blisko roku od jego wprowadzenia, Warszawa.

GUS (2016), Rocznik Statystyczny Rzeczpospolitej Polskiej, Warszawa.

Ustawa z dnia 11 lutego 2016 r. o pomocy państwa w wychowaniu dzieci [Law of February 11, 2016 on state aid in childcare] (2016), Dz. U. [O.J.] 2016, item 195.

Ustawa z dnia 16 listopada 2016 r. o zmianie ustawy o powszechnym obowiązku obrony Rzeczpospolitej Polskiej oraz niektórych innych ustaw [Law of November 16, 2016 amending the law on the universal obligation to defend the Republic of Poland and certain other laws] (2016), Dz. U. [O.J.] 2016, item 2138.

Ustawa z dnia 16 listopada 2016 roku o zmianie ustawy o emeryturach i rentach z Funduszu Ubezpieczeń Społecznych oraz niektórych innych ustaw [Law of November 16, 2016 amending the law on pensions and benefits granted by the Social Security Fund and certain other laws] (2017), Dz. U. [O.J.] 2017, item 38, 1452.

\begin{abstract}
The aim of the article is to present the results of studies carried out in Wielkopolska regarding the perception of security by local communities, declared priorities and the impact of public debate and the media on these priorities. The studies were carried out in the former administrative region of Konin in 2015, 2016 and 2017. As the analysis shows, the narrative regarding
\end{abstract}


individual and collective threats presented by politicians and the media had a large impact on individual priorities. This is evident from the assessment of the threat to national security and the assessment of such phenomena as terrorism, immigrants or the possibility of aggression from the East. With regard to individual security and changing priorities in this area, the impact of stabilization resulting from the implementation of social programs of the Law and Justice Party, with a special focus on the "Family 500 plus" program, is clearly noticeable. The results of the studies explicitly recommend their continuation in the years to come.

Keywords: internal security, security priorities, security assessment, sense of security

\section{PRIORYTETY BEZPIECZEŃSTWA - POSTRZEGANIE Z PERSPEKTYWY SPOŁECZNOŚCI LOKALNYCH. BADANIA MIESZKAŃCÓW WIELKOPOLSKI - 2015-2017}

\section{STRESZCZENIE}

Celem artykułu jest przedstawienie wyników badań przeprowadzonych w Wielkopolsce, dotyczących postrzegania bezpieczeństwa przez społeczność lokalną, deklarowanych priorytetów oraz wpływu debaty publicznej i mediów na nie. Badania zostały przeprowadzone w byłym województwie konińskim w latach 2015, 2016 i 2017. Jak wynika z przeprowadzonej analizy, duży wpływ na priorytety indywidualne ma narracja obejmująca zagrożenia indywidualne i zbiorowe przedstawiane przez polityków oraz media. Widać to na przykładzie oceny zagrożenia bezpieczeństwa państwa oraz oceny takich zjawisk jak terroryzm, imigranci czy możliwości agresji ze Wschodu. W odniesieniu do bezpieczeństwa indywidualnego oraz zmiany priorytetów w tym zakresie wyraźnie zauważalny jest wpływ stabilizacji związanej z realizacją programów społecznych Prawa i Sprawiedliwości ze szczególnym uwzględnieniem programu „Rodzina 500 plus”. Wyniki przedstawionych badań jednoznacznie rekomendują dalsze ich kontynuowanie w kolejnych latach.

Słowa kluczowe: bezpieczeństwo wewnętrzne, priorytety bezpieczeństwa, ocena bezpieczeństwa, poczucie bezpieczeństwa 